\title{
Molecular variability among isolates of Mycosphaerella graminicola, the causal agent of septoria tritici blotch, in Argentina
}

\author{
N. Castillo • C. Cordo • M. R. Simón
}

Received: 16 July 2009 / Accepted: 4 July 2010 / Published online: 29 July 2010

(C) Springer Science+Business Media B.V. 2010

\begin{abstract}
The genetic structure and diversity of Mycosphaerella graminicola population were studied with ISSR molecular markers, using isolates from several locations of the Argentinean wheat region: subregion IV (SE of Buenos Aires Province) and II South (central part of Buenos Aires Province). Samples were taken from different bread wheat (Triticum aestivum) cultivars. A total of 126 isolates were subjected to molecular analysis to compare the genetic structure of the isolates from both wheat subregions. Ten ISSR primers were used: (GACA) 4 ; $(\mathrm{AAC})_{7} ;(\mathrm{ATC})_{7} ;(\mathrm{AC})_{9} ;(\mathrm{AAG})_{7} ;(\mathrm{AG})_{9} ;(\mathrm{AGC})_{5}$; $(\mathrm{CAG})_{5},(\mathrm{GTG})_{5}$ and $(\mathrm{GACAC})_{3}$. Eighty-four bands ranging from $200 \mathrm{bp}$ to 8.000 were amplified. Eighty-one distinct haplotypes were identified and 43 isolates did not generate any amplification products. The highest number of polymorphic DNA fragments were produced using ISSR primers $(\mathrm{ATC})_{7}$ and $(\mathrm{GTG})_{5}$, which detected bands in 38
\end{abstract}

N. Castillo $(\bowtie) \cdot$ M. R. Simón

Cerealicultura,

Facultad de Ciencias Agrarias y Forestales,

Universidad Nacional de La Plata,

Buenos Aires, Argentina

e-mail: nadiacastillo22@yahoo.com.ar

C. Cordo

CIDEFI (Centro de Investigaciones de Fitopatología) - CIC

(Centro de Investigaciones Científicas

de la Provincia de Buenos Aires), Facultad de Ciencias

Agrarias y Forestales, Universidad Nacional de La Plata,

Buenos Aires, Argentina isolates. The molecular analysis revealed the existence of 81 different haplotypes among the 126 isolates studied. These results revealed a high degree of genetic diversity in the $M$. graminicola population in Argentina.

Keywords Dendrogram - Genetic diversity . Haplotypes · ISSR · Population

\section{Introduction}

Bread wheat (Triticum aestivum L.) is the most widely grown and consumed food crop in the world. It is the staple food of nearly $35 \%$ of the world's population, and its demand will grow faster than for any other major crop (Rajaram 1999). Mycosphaerella graminicola (Fuckel) Schroeter in Cohn (anamorph Septoria tritici Rob. ex Desm.), which is a haploid, heterothallic ascomycete (Kema et al. 1996) and one of the most destructive fungal pathogens of wheat (King et al. 1983), causes septoria tritici blotch. Septoria tritici blotch causes economically significant yield losses in most of the wheat-growing areas of the world $(31 \%$ to $54 \%$ in climates prone to disease development (Eyal et al. 1985)). In Argentina, Annone et al. $(1991,1993)$ reported yield losses from $20 \%$ to $50 \%$ and Simon et al. (1996) found reductions of $3 \%$ to $13 \%$ in the 1,000 -kernel weight. Although several control methods, including the use of fungicides and other cultural practices, may 
reduce the effect of septoria tritici blotch on yield, genetic resistance is the most cost-effective and environmentally safe technique for managing the disease (Simon et al. 2002, 2003).

The genetic structure of $M$. graminicola populations has been studied for over a decade (e.g. Schnieder et al. 2001; Zhan et al. 2003) and several molecular methods, such as RAPD, AFLP, SSRs and ISSR, have been used to analyze the diversity of this pathogenic fungus (Meng and Chen 2001; Sartorato 2004; Wagara et al. 2004). Microsatellites or SSR (Simple Sequence Repeats) are tandem repeat motifs composed of one to six nucleotides, which are ubiquitous, abundant and highly polymorphic in most eukaryotic genomes (Tautz and Renz 1984). ISSR (Intersimple Sequence Repeat) technique consists in the amplification of DNA sequences between SSR by means of anchored or non-anchored SSR homologous primers (Zietkiewicz et al. 1994). Unlike SSR, ISSR does not require previous knowledge of the sequence and generates specific and reproducible patterns due to the highly stringent conditions of the reaction (Bornet and Branchard 2001). The first studies with ISSR markers demonstrated the hypervariable nature of these markers (Wolfe and Liston 1998). The ISSR techniques are nearly identical to the RAPD techniques, except for the fact that ISSR primer sequences are designed from microsatellite regions and the annealing temperatures used are higher than those used for RAPD markers. Based on the published and in-progress studies conducted using ISSR markers, it is clear that these markers have great potential for studying natural populations (Wolfe et al. 1998).

Many studies using different molecular markers have shown that there is a high level of genetic diversity within the populations of $M$. graminicola and that the population is composed of many different genotypes. Czembor and Arseniuk (1999) studied different species of Septoria (S. avenae f.sp. triticea, $S$. nodorum and $S$. tritici) and found that SSR and ISSR markers are the most sensitive ones for the detection of DNA polymorphisms. Extensive population genetic analyses of $M$. graminicola have also been conducted with RFLP markers (Linde et al. 2002), and AFLP and RAPD markers have been used to construct a genetic linkage map (Kema et al. 2002). Schnieder et al. (2001) used AFLP markers to analyze one population of M. graminicola from Germany, and observed high within-population diversity and that the significant migration between populations prevented genetic isolation and differentiation of putative geographically separated populations. Working on a total of 90 isolates of M. graminicola from western Canada (University of Saskatchewan, Saskatoon) and using RAPD, Razavi and Hughes (2004) detected a high degree of DNA polymorphism with a large number of different molecular phenotypes. Kabbage et al. (2008) studied the genetic structure of populations of $M$. graminicola from Kansas at different spatial scales (micro-plot, macro-plot, and statewide) using AFLP and found genetic identities higher than $98 \%$ among populations. Tests for population subdivision revealed that $98 \%$ of the genetic diversity occurred within populations (Kabbage et al. 2008). By using AFLP analysis, Medini and Hamza (2008) revealed a high level of genetic diversity in populations of $M$. graminicola isolates, obtained no clones and found that each isolate showed a unique haplotype. Recently, Goodwin et al. (2007) analyzed a database of 30,137 EST (expressed sequence tag) sequences (Kema et al. 2003) from M. graminicola and identified 38 di- and 71 trinucleotide microsatellites with repeat numbers of six or more. Microsatellites that showed polymorphism between the parents of the $M$. graminicola mapping population were integrated into the existing genetic linkage map (Kema et al. 2002). The EST database provided an excellent source of new, highly polymorphic microsatellite markers that can be multiplexed for high-throughput genetic analyses of $M$. graminicola and related species.

In Argentina, M. graminicola has been studied with a limited set of isolates of the pathogen from some areas, using RFLP and it has been found that the pathogen has a high virulence degree variation (Cordo et al. 2006). Using RFLP, Jürgens et al. (2006) compared five populations from Los Hornos, Balcarce and Barrow (all in the Province of Buenos Aires) and determined that the populations from uninoculated fields in Argentina had higher gene and genotype diversities than those from inoculated fields. However, knowledge of the extent of the genetic diversity and of how the pathogen population may vary in different subregions in Argentina is still lacking.

Information about the genetic diversity of $M$. graminicola is very important because it could allow us to determine which genotypes predominate within 
a certain geographic area and to evaluate the wheat germplasm resistance of Argentinean cultivars with isolates with high genetic differences. The aim of this study was to extend the study of the genetic structure and diversity of $M$. graminicola population to a large number of isolates from several locations of the wheat region, namely subregion IV (SE of Buenos Aires Province) and II South (central part of Buenos Aires Province), by means of ISSR molecular markers. Our hypotheses were that $(a)$ the population of $M$. graminicola has a high genetic diversity and that groups with similar molecular patterns consist mainly of isolates belonging to the same wheat region, and thus, that differences among them are related to the geographic area; and $(b)$ it is possible to select within them a huge set of completely different isolates to test the local wheat germplasm.

\section{Materials and methods}

Collection and multiplication of isolates Infected leaf tissues were randomly collected from different bread wheat (Triticum aestivum) cultivars growing in different locations in Argentina: Necochea and Tres Arroyos (wheat subregion IV) and 9 de Julio and Pla (wheat subregion II South) (Fig. 1). In addition, random samples were taken from the whole set of commercial cultivars grown in the trials of the National Argentinean Net of Cultivars (RET). At each location, the leaves were obtained from four different fields which were approximately $2 \mathrm{~km}$ apart from each other. Eight sites (two in each field) were sampled and ten to 15 leaves were collected in each site. All the samples from Necochea and Tres Arroyos were collected in 2005 and the most samples from 9

Fig. 1 Map of Argentinean Wheat Region showing the locations where $\mathrm{Myco}$ phaerella graminicola isolates were collected. $N=$ Necochea; $N J=9$ de Julio; $P=$ Pla; $T=$ Tres Arroyos

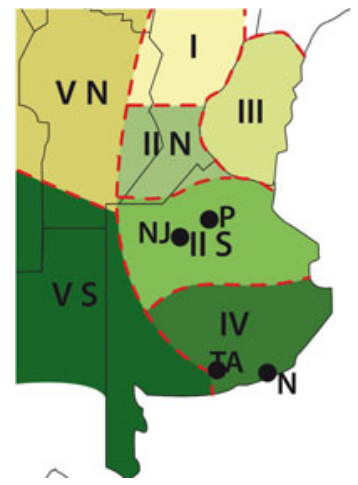

de Julio and Pla in 2007, except some samples from 9 de Julio which were collected in 2005. Leaves were disinfected using a routine disinfection technique (alcohol $70 \%$ for $10 \mathrm{~s}, 2 \%$ sodium hypochlorite commercial, $55 \mathrm{~g} \mathrm{Cl}^{-1}$ for $90 \mathrm{~s}$ and finally rinsed twice in fresh sterilized distilled water for $90 \mathrm{~s}$ each time).

Forty-two petri dishes with three leaves each were incubated for 2 days at room temperature $\left(18-22^{\circ} \mathrm{C}\right)$. Then, one pycnidium was taken from each leaf and placed on a petri dish with yeast malt agar (YMA) broth (Eyal et al. 1987) at room temperature for 5-7 days. From single colonies, we obtained a total of 126 monosporic isolates (53 from Necochea, 13 from Tres Arroyos, 54 from 9 de Julio and 6 from Pla). The codes, names and origin of the $M$. graminicola isolates used are indicated in Table 1. The monosporic isolates were grown in yeast sucrose broth liquid media at room temperature $\left(20-22^{\circ} \mathrm{C}\right)$ by shaking (150 rpm) for 10 days to obtain the spore suspension for further DNA extraction (McDonald and Martinez 1990). The fungal spores were lyophilized and stored at $-20^{\circ} \mathrm{C}$ until DNA extraction.

DNA extraction, ISSR amplification and electrophoresis DNA was extracted from each isolate using a CTAB extraction protocol (Ferreira and Grattapaglia 1998). The concentration of DNA was measured with a fluorometer (Invitrogen Qubit ${ }^{\mathrm{TM}}$ Fluorometer). The stock solution of DNA ( $5 \mathrm{ng} \mu \mathrm{l}^{-1}$ concentration) was prepared for each isolate and stored at $-20^{\circ} \mathrm{C}$. DNA was amplified with the ISSR molecular technique. Ten ISSR primers were selected according to previous data (Czembor and Arseniuk 1999): (GACA $)_{4} ;(\mathrm{AAC})_{7}$; $(\mathrm{ATC})_{7} ;(\mathrm{AC})_{9} ;(\mathrm{AAG})_{7} ;(\mathrm{AG})_{9} ;(\mathrm{AGC})_{5} ;(\mathrm{CAG})_{5}$; $(\mathrm{GTG})_{5}$ and $(\mathrm{GACAC})_{3}$ with different annealing temperatures (Table 2).

Every $20 \mu \mathrm{l}$ reaction mixture contained: $5 \times$ PCR buffer minus $\mathrm{Mg}^{-2}$ (Invitrogen, Carslbad, CA, USA), $25 \mathrm{mM} \mathrm{MgCl}_{2}$ (Invitrogen), $200 \mu \mathrm{M}$ each of dATP, dTTP, dCTP and dGTP (Promega, Madison, WI, USA), $5 \mathrm{mM}$ ISSR primer (Promega), $0.5 \mathrm{U}$ of Taq DNA Polymerase (Invitrogen) and approximately $5 \mathrm{ng}$ of template DNA. Amplification was carried out in a thermocycler with gradient (Thermo Electron Corporation, Milford, MA, USA), programmed first at $95^{\circ} \mathrm{C}$ for $120 \mathrm{~s}$, then for 40 cycles of denaturation at $94^{\circ} \mathrm{C}$ for $20 \mathrm{~s}$ and the annealing temperature for each ISSR primer for $20 \mathrm{~s}$ and elongation at $72^{\circ} \mathrm{C}$ for 
Table 1 Codes, names, origins and year of collection of Mycosphaerella graminicola isolates used in this study. Letters following each code indicate the origin of each isolate $(\mathrm{N}$ : Necochea; TA: Tres Arroyos; P: Pla; NJ: 9 de Julio)

\begin{tabular}{|c|c|c|c|c|}
\hline $\begin{array}{l}\text { Isolate } \\
\text { code }\end{array}$ & $\begin{array}{l}\text { Name of } \\
\text { isolate }\end{array}$ & $\begin{array}{l}\text { Origin } \\
\text { (location) }\end{array}$ & $\begin{array}{l}\text { Year of } \\
\text { collection }\end{array}$ & $\begin{array}{l}\text { Argentinean } \\
\text { wheat subregion }\end{array}$ \\
\hline $1 \mathrm{~N}$ & FALP00105 & Necochea & 2005 & IV \\
\hline $2 \mathrm{~N}$ & FALP00205 & Necochea & 2005 & IV \\
\hline $3 \mathrm{~N}$ & FALP00305 & Necochea & 2005 & IV \\
\hline $20 \mathrm{~N}$ & FALP02005 & Necochea & 2005 & IV \\
\hline $24 \mathrm{~N}$ & FALP02405 & Necochea & 2005 & IV \\
\hline $26 \mathrm{~N}$ & FALP02605 & Necochea & 2005 & IV \\
\hline $30 \mathrm{~N}$ & FALP03005 & Necochea & 2005 & IV \\
\hline $33 \mathrm{~N}$ & FALP03305 & Necochea & 2005 & IV \\
\hline $35 \mathrm{~N}$ & FALP03505 & Necochea & 2005 & IV \\
\hline $38 \mathrm{~N}$ & FALP03805 & Necochea & 2005 & IV \\
\hline $39 \mathrm{~N}$ & FALP03905 & Necochea & 2005 & IV \\
\hline $43 \mathrm{~N}$ & FALP04305 & Necochea & 2005 & IV \\
\hline $44 \mathrm{~N}$ & FALP04405 & Necochea & 2005 & IV \\
\hline $56 \mathrm{~N}$ & FALP05605 & Necochea & 2005 & IV \\
\hline $70 \mathrm{~N}$ & FALP07005 & Necochea & 2005 & IV \\
\hline $72 \mathrm{~N}$ & FALP07205 & Necochea & 2005 & IV \\
\hline $74 \mathrm{~N}$ & FALP07405 & Necochea & 2005 & IV \\
\hline $75 \mathrm{~N}$ & FALP07505 & Necochea & 2005 & IV \\
\hline $76 \mathrm{~N}$ & FALP07605 & Necochea & 2005 & IV \\
\hline $77 \mathrm{~N}$ & FALP07705 & Necochea & 2005 & IV \\
\hline $78 \mathrm{~N}$ & FALP07805 & Necochea & 2005 & IV \\
\hline $79 \mathrm{~N}$ & FALP07905 & Necochea & 2005 & IV \\
\hline $81 \mathrm{~N}$ & FALP08105 & Necochea & 2005 & IV \\
\hline $82 \mathrm{~N}$ & FALP08205 & Necochea & 2005 & IV \\
\hline $83 \mathrm{~N}$ & FALP08305 & Necochea & 2005 & IV \\
\hline $85 \mathrm{~N}$ & FALP08505 & Necochea & 2005 & IV \\
\hline $87 \mathrm{~N}$ & FALP08705 & Necochea & 2005 & IV \\
\hline $95 \mathrm{~N}$ & FALP09505 & Necochea & 2005 & IV \\
\hline $97 \mathrm{~N}$ & FALP09705 & Necochea & 2005 & IV \\
\hline $98 \mathrm{~N}$ & FALP09805 & Necochea & 2005 & IV \\
\hline $99 \mathrm{~N}$ & FALP09905 & Necochea & 2005 & IV \\
\hline $100 \mathrm{~N}$ & FALP10005 & Necochea & 2005 & IV \\
\hline $102 \mathrm{~N}$ & FALP10205 & Necochea & 2005 & IV \\
\hline $103 \mathrm{~N}$ & FALP10305 & Necochea & 2005 & IV \\
\hline $105 \mathrm{~N}$ & FALP10505 & Necochea & 2005 & IV \\
\hline $106 \mathrm{~N}$ & FALP10605 & Necochea & 2005 & IV \\
\hline $120 \mathrm{~N}$ & FALP12005 & Necochea & 2005 & IV \\
\hline $122 \mathrm{~N}$ & FALP12205 & Necochea & 2005 & IV \\
\hline $129 \mathrm{~N}$ & FALP12905 & Necochea & 2005 & IV \\
\hline $130 \mathrm{~N}$ & FALP13005 & Necochea & 2005 & IV \\
\hline $137 \mathrm{~N}$ & FALP13705 & Necochea & 2005 & IV \\
\hline $142 \mathrm{~N}$ & FALP14205 & Necochea & 2005 & IV \\
\hline $149 \mathrm{~N}$ & FALP14905 & Necochea & 2005 & IV \\
\hline
\end{tabular}

Table 1 (continued)

Isolate Name of Origin Year of Argentinean code isolate (location) collection wheat subregion

\begin{tabular}{|c|c|c|c|c|}
\hline $152 \mathrm{~N}$ & FALP15205 & Necochea & 2005 & IV \\
\hline 47TA & FALP04805 & Tres Arroyos & 2005 & IV \\
\hline 49TA & FALP04905 & Tres Arroyos & 2005 & IV \\
\hline $50 \mathrm{TA}$ & FALP05005 & Tres Arroyos & 2005 & IV \\
\hline $52 \mathrm{TA}$ & FALP05205 & Tres Arroyos & 2005 & IV \\
\hline 89TA & FALP08905 & Tres Arroyos & 2005 & IV \\
\hline 93TA & FALP09305 & Tres Arroyos & 2005 & IV \\
\hline $203 \mathrm{P}$ & FALP20307 & Pla & 2007 & II South \\
\hline $205 \mathrm{P}$ & FALP20507 & Pla & 2007 & II South \\
\hline $224 \mathrm{P}$ & FALP22407 & Pla & 2007 & II South \\
\hline $201 \mathrm{NJ}$ & FALP20107 & 9 de Julio & 2007 & II South \\
\hline $202 \mathrm{NJ}$ & FALP20207 & 9 de Julio & 2007 & II South \\
\hline $208 \mathrm{NJ}$ & FALP20807 & 9 de Julio & 2007 & II South \\
\hline $214 \mathrm{NJ}$ & FALP21407 & 9 de Julio & 2007 & II South \\
\hline $215 \mathrm{NJ}$ & FALP21507 & 9 de Julio & 2007 & II South \\
\hline $217 \mathrm{NJ}$ & FALP21707 & 9 de Julio & 2007 & II South \\
\hline $225 \mathrm{NJ}$ & FALP22507 & 9 de Julio & 2007 & II South \\
\hline $226 \mathrm{NJ}$ & FALP22607 & 9 de Julio & 2007 & II South \\
\hline $227 \mathrm{NJ}$ & FALP22707 & 9 de Julio & 2007 & II South \\
\hline $228 \mathrm{NJ}$ & FALP22807 & 9 de Julio & 2007 & II South \\
\hline $229 \mathrm{NJ}$ & FALP22907 & 9 de Julio & 2007 & II South \\
\hline $230 \mathrm{NJ}$ & FALP23007 & 9 de Julio & 2007 & II South \\
\hline $232 \mathrm{NJ}$ & FALP23207 & 9 de Julio & 2007 & II South \\
\hline $236 \mathrm{NJ}$ & FALP23607 & 9 de Julio & 2007 & II South \\
\hline $237 \mathrm{NJ}$ & FALP23707 & 9 de Julio & 2007 & II South \\
\hline $238 \mathrm{NJ}$ & FALP23807 & 9 de Julio & 2007 & II South \\
\hline $239 \mathrm{NJ}$ & FALP23907 & 9 de Julio & 2007 & II South \\
\hline $244 \mathrm{NJ}$ & FALP24407 & 9 de Julio & 2007 & II South \\
\hline $247 \mathrm{NJ}$ & FALP24707 & 9 de Julio & 2007 & II South \\
\hline $248 \mathrm{NJ}$ & FALP24807 & 9 de Julio & 2007 & II South \\
\hline $249 \mathrm{NJ}$ & FALP24907 & 9 de Julio & 2007 & II South \\
\hline $250 \mathrm{NJ}$ & FALP25007 & 9 de Julio & 2007 & II South \\
\hline $253 \mathrm{NJ}$ & FALP25307 & 9 de Julio & 2007 & II South \\
\hline $254 \mathrm{NJ}$ & FALP25405 & 9 de Julio & 2005 & II South \\
\hline $255 \mathrm{NJ}$ & FALP25505 & 9 de Julio & 2005 & II South \\
\hline $260 \mathrm{NJ}$ & FALP26005 & 9 de Julio & 2005 & II South \\
\hline $265 \mathrm{NJ}$ & FALP26505 & 9 de Julio & 2005 & II South \\
\hline $291 \mathrm{NJ}$ & FALP29105 & 9 de Julio & 2005 & II South \\
\hline $292 \mathrm{NJ}$ & FALP29205 & 9 de Julio & 2005 & II South \\
\hline $293 \mathrm{NJ}$ & FALP29305 & 9 de Julio & 2005 & II South \\
\hline
\end{tabular}

$120 \mathrm{~s}$. The final primer elongation segment of the run was extended to $12 \mathrm{~min}$ at $72^{\circ} \mathrm{C}$ (Czembor and Arseniuk 1999). Each reaction was performed at least twice. 
Table 2 ISSR primers used in this study

\begin{tabular}{llc}
\hline Primer code & Primer sequence $5^{\prime} \rightarrow 3^{\prime}$ & Annealing temperature $\left({ }^{\circ} \mathrm{C}\right)$ \\
\hline$($ GACA $) 4$ & GACAGACAGACAGACA & 44 \\
$($ AAC $) 7$ & AACAACAACAACAACAACAAC & 48 \\
$($ ATC $) 7$ & ATCATCATCATCATCATCATC & 44 \\
$(\mathrm{AC}) 9$ & ACACACACACACACACAC & 54 \\
$(\mathrm{AAG}) 7$ & AAGAAGAAGAAGAAGAAGAAG & 48 \\
$(\mathrm{AG}) 9$ & AGAGAGAGAGAGAGAGAG & 44 \\
$(\mathrm{AGC}) 5$ & AGCAGCAGCAGCAGC & 48 \\
$(\mathrm{CAG}) 5$ & CAGCAGCAGCAGCAG & 48 \\
$(\mathrm{GTG}) 5$ & GTGGTGGTGGTGGTG & 48 \\
$(\mathrm{GACAC}) 3$ & GACACGACACGACAC & 44 \\
\hline
\end{tabular}

PCR products were separated on $2 \%$ agarose gels in $1 \mathrm{X}$ TBE buffer at $150 \mathrm{~V}$ for $4.30 \mathrm{~h}$. Two molecular weight markers (100 bp and $1 \mathrm{~kb}$ ) were included. The products were stained with SyBr-Green (Invitrogen) (1:100) and DNA banding patterns were visualized under UV light and photographed on a transilluminator.

Data analysis Banding patterns were scored for the presence (1) or absence (0) of bands for each ISSRprimer-isolate combination and data were entered into a binary matrix (similarity matrix). In the similarity matrix, a value of 1 indicated maximum similarity (identical isolates) and a value of 0 indicated minimum similarity (completely different isolates).

All pairs of isolates were then compared applying Dice's coefficient (Nei and Li 1979). The similarity matrix was then used to construct a dendrogram using the unweighted pair group method of arithmetic average (UPGMA) with the NTSyS-pc software (Rohlf 1998) (Fig. 2). Genotype diversity (G) in each population was calculated according to Stoddart and Taylor (1988). The gene flow between the subregions was estimated by the method described by Nei (1972), who estimated the average number of individuals per generation that migrate between the populations.

\section{Results}

All primers generated polymorphisms. Eighty-four polymorphic bands ranging from $200 \mathrm{bp}$ to 8.000 were generated by the ten ISSR primers used. From a total of 126 isolates, 83 isolates were amplified and
81 distinct genotypes were identified. Isolates $74 \mathrm{~N}$ and $250 \mathrm{NJ}$ and isolates $205 \mathrm{P}$ and $208 \mathrm{NJ}$ showed identical patterns. On the other hand, 43 isolates did not generate any amplification products with the ten ISSR primers used. Fourteen of those 43 isolates belonged to Necochea, two to Tres Arroyos (subregion II South), 24 to 9 de Julio and three to Pla (subregion IV). The highest number of polymorphic DNA fragments were produced using ISSR primers $(\text { ATC })_{7}$ and $(\mathrm{GTG})_{5}$. These ISSR primers detected 84 polymorphic bands in 38 isolates among the 126 isolates analyzed. On the other hand, the ISSR primer $(\mathrm{CAG})_{5}$ separated only ten isolates.

The dendrogram generated by the similarity matrix based on Dice's coefficient and the UPGMA clustering algorithm showed that at the 0.20 similarity level, 13 distinct clusters (I, II, III, IV, V, VI, VII, VIII, IX, X, XI, XII and XIII) were detected (Fig. 2). The 13 clusters formed in the dendrogram and their respective isolates are shown in Table 3. Cluster I, within which isolates $102 \mathrm{~N}$ and $103 \mathrm{~N}$, and $202 \mathrm{NJ}$ and $236 \mathrm{NJ}$ were the most related (distance coefficient 0.75 ), included 50 isolates. Cluster II, within which $74 \mathrm{~N}$ and $250 \mathrm{NJ}$ were identical and $137 \mathrm{~N}$ and $149 \mathrm{~N}$ were the most related (distance coefficient 0.75 ), was composed of 12 isolates. Cluster III included only two isolates from Necochea, separated by a distance coefficient of 0.52 . In cluster IV, the isolates were related by a genetic distance of 0.50 , and isolates 205P and 208NJ were identical (genetic distance 1.00). Clusters $\mathrm{V}$ and IX were formed by two isolates related by 0.34 and 0.23 distance coefficient, respectively, whereas cluster VI was formed by only one isolate. Cluster VIII included isolates $201 \mathrm{NJ}, 214 \mathrm{NJ}$ and $203 \mathrm{P}$ and cluster IX was formed by two isolates: $93 \mathrm{TA}$ and $254 \mathrm{NJ}$, separated by 


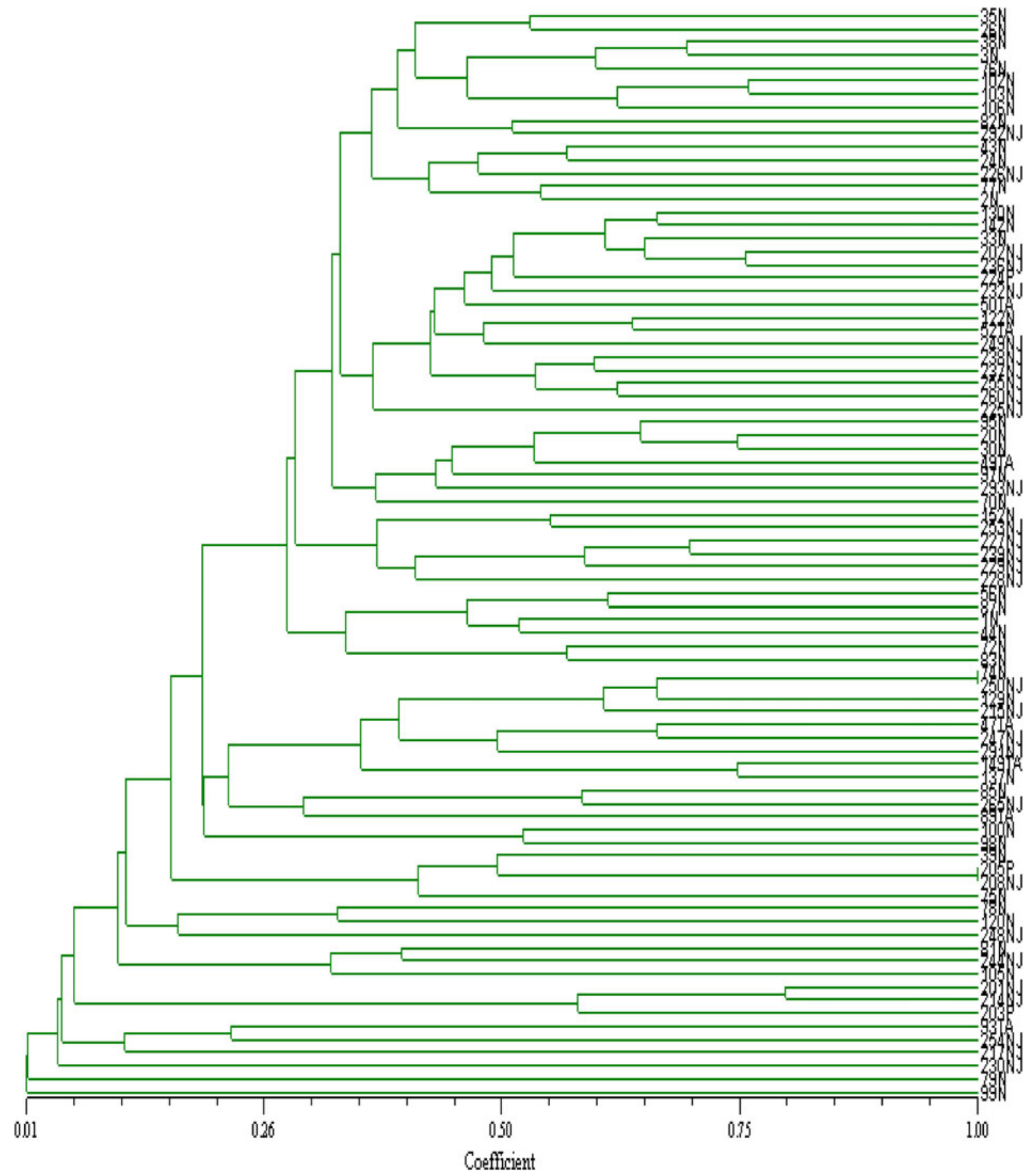

Fig. 2 Cluster analysis dendrogram for 83 isolates of Mycosphaerella graminicola, based on ISSR molecular markers using the unweighted pair group method of arithmetic average (UPGMA) with the NTSyS-pc software

a 0.23 distance coefficient. Finally, clusters X, XI, XII and XIII, which were formed by the isolates $217 \mathrm{NJ}$, $230 \mathrm{NJ}, 79 \mathrm{~N}$ and $99 \mathrm{~N}$, respectively, had the largest genetic distance from the other groups.
The maximum similarity was approximately $100 \%$ between isolates $74 \mathrm{~N}$ and $250 \mathrm{NJ}$ and between isolates $205 \mathrm{P}$ and 208NJ. Each isolate was considered identical with its pair. The minimum similarity was 
Table 3 Cluster analysis and isolates in each cluster

\begin{tabular}{|c|c|c|}
\hline & Isolates & Origin \\
\hline Cluster I & $\begin{array}{l}1,2,3,20,24,26,30,33,35,38,43,44,49,56, \\
70,72,76,77,82,83,87,95,97,102,103,106, \\
122,130,142,152,225,227,239,253 \text { and } 293 . \\
50 \text { and } 52 \\
202,226,228,229,232,236,237,238,249,255,260 \text { and } 292 \\
224\end{array}$ & $\begin{array}{l}\text { Necochea } \\
\text { Tres Arroyos } \\
9 \text { de Julio } \\
\text { Pla }\end{array}$ \\
\hline Cluster II & $\begin{array}{l}74,85,137 \text { and } 149 \\
215,247,250,265 \text { and } 291 \\
47 \text { and } 89\end{array}$ & $\begin{array}{l}\text { Necochea } \\
9 \text { de Julio } \\
\text { Tres Arroyos }\end{array}$ \\
\hline Cluster III & 98 and 100 & Necochea \\
\hline Cluster IV & $\begin{array}{l}39 \text { and } 75 \\
205 \\
208\end{array}$ & $\begin{array}{l}\text { Necochea } \\
\text { Pla } \\
9 \text { de Julio }\end{array}$ \\
\hline Cluster V & 78 and 120 & Necochea \\
\hline Cluster VI & 248 & 9 de Julio \\
\hline Cluster VII & $\begin{array}{l}81 \text { and } 105 \\
244\end{array}$ & $\begin{array}{l}\text { Necochea } \\
9 \text { de Julio }\end{array}$ \\
\hline Cluster VIII & $\begin{array}{l}201 \text { and } 214 \\
203\end{array}$ & $\begin{array}{l}9 \text { de Julio } \\
\text { Pla }\end{array}$ \\
\hline Cluster IX & $\begin{array}{l}93 \\
254\end{array}$ & $\begin{array}{l}\text { Tres Arroyos } \\
9 \text { de Julio }\end{array}$ \\
\hline Cluster X & 217 & 9 de Julio \\
\hline Cluster XI & 230 & 9 de Julio \\
\hline Cluster XII & 79 & Necochea \\
\hline Cluster XIII & 99 & Necochea \\
\hline
\end{tabular}

$\sim 1 \%$ and separated isolate $99 \mathrm{~N}$ from the rest, indicating that this isolate is the most different from the others. Genotype diversity was always greater in the subregion IV population than in the subregion II South population. Genotype diversity was $G=21.73 \%$ in the subregion IV population and $G=7.86 \%$ in the subregion II South population when we considered all the isolates (including those that had no amplification), assuming that those that had no amplification were different from the rest. Differences between populations were significant (test $P=0.01$ ). When the isolates that did not amplify were not included, G was $100 \%$ for the population from subregion IV and $94.3 \%$ for that from subregion II South (Table 4). The amount of gene flow among populations $(\mathrm{Nm})$ across all loci was 7.21 when all the isolates were included, indicating that more than seven individuals moved between subregions every generation. $\mathrm{Nm}$ across all loci was 11.37 when we included only the isolates that amplified, indicating that more than 11 individuals moved between subregions every generation.

\section{Discussion}

The ISSR markers used in this study revealed a high degree of genetic diversity within the M. graminicola population and detected 81 different molecular genotypes among the 83 isolates amplified [Genotype diversity ( $G=21.73 \%$ or $100 \%$ (subregion IV) and $7.86 \%$ or $94.3 \%$ (subregion II South)]. Our results are in agreement with previous works carried out in other countries, where different degrees of genetic diversity among M. graminicola populations were found by using different molecular markers (Schnieder et al. 2001; Zhan et al. 2003). High genotypic diversities have been detected in different populations analyzed using RFLP (Linde et al. 2002) and AFLP (Kabbage et al. 2008). 
Table 4 Information on two populations of Septoria tritici from two Argentinean wheat subregions

Subregion IV Subregion II South

\begin{tabular}{|c|c|c|}
\hline Total No. of isolates & 67 & 60 \\
\hline Isolates that amplified & 50 & 33 \\
\hline $\begin{array}{l}\text { Isolates that did not } \\
\text { amplify }\end{array}$ & 17 & 27 \\
\hline No. of genotypes & 50 & 31 \\
\hline $\begin{array}{l}\text { Genotypic diversity } \\
\text { (including all isolates) }\end{array}$ & 21.73 & 7.86 \\
\hline $\begin{array}{l}\text { Genotypic diversity } \\
\text { (including isolates that } \\
\text { did not amplify) }\end{array}$ & 100 & 94.3 \\
\hline
\end{tabular}

Our analysis showed that there was higher genotype diversity in the population from wheat subregion IV than in that from subregion II South. Our results are in agreement with those of Jürgens et al. (2006) and Cordo et al. (2006), who found different rates of genotype diversity when comparing populations in Argentina using RFLP. Jürgens et al. (2006) studied five populations from three different locations: Los Hornos (ARG1 and ARG5), Balcarce (ARG2) and Barrow (ARG3 and ARG4), and found that $65 \%$ of all isolates were unique genotypes. Likewise, Cordo et al. (2006) studied the populations from Balcarce (subregion IV) and Los Hornos (subregion II South), and found 39 genotypes among 62 isolates of the pathogen in Balcarce and 35 unique genotypes among a total of 58 isolates in Los Hornos. Genotype diversity was greater in the Balcarce population $(G=31.61 \%)$ than in the Los Hornos population $(G=26.19 \%)$. Los Hornos exhibited a high level of clonality because it is not an endemic area for the leaf blotch of wheat and artificial inoculation with the pathogen, which causes a low genotypic diversity, is normally used. Instead, in our study, we took isolates from naturally infected wheat fields from a wider region and found that the level of clonality was low within both populations and that only four genotypes were identical. A high level of diversity in the nuclear genome is typical of field populations of M. graminicola (Zhan et al. 2003).

In this study, we obtained only four identical genotypes and 81 different genotypes. The cluster analysis showed that the maximum similarity between isolates of M. graminicola was $100 \%$. In agreement with our results, Razavi and Hughes (2004), using
RAPD molecular markers in a $M$. graminicola population from western Canada, found $100 \%$ genotypic diversity among a total of 87 isolates and showed that the maximum similarity between isolates of $M$. graminicola was approximately $81 \%$ and that there were no identical isolates.

In addition, our results indicate differences between isolates from wheat subregion IV and isolates from wheat subregion II South. We assumed that most of the variation can be attributed to a different composition of the population in both subregions. Furthermore, it is necessary to take into account that isolates for both subregions were randomly taken from all the commercial cultivars in different years, which could have added more variation between the subregions. Jürgens et al. (2006) also found that the Argentinean populations ARG1, ARG2 and ARG3 differed significantly in genotype diversity.

The consideration of the genetic variation of $M$. graminicola populations is essential to understand the virulence in the different cultivars. Differences around the world could be attributed to factors such as variations in the regular recombination, different migration patterns, and presence and importance of the sexual form. The sexual reproduction of $M$. graminicola, which is known to be present in Argentina (Cordo et al. 1990), allows the existence of a large number of genetically diverse isolates. Populations in this fungus are in genetic equilibrium as well as in drift migration equilibrium (Chen and McDonald 1996), attributed to a high rate of sexual recombination (Cordo et al. 2006). In most of the wheat areas of the world, the sexual form of $M$. graminicola has been reported as a primary source of inoculum. Regular sexual reproduction provides this pathogen with a mechanism to generate novel allele combinations rapidly, whereas asexual reproduction, gene flow, and natural selection ensure the maintenance and rapid dissemination of allele combinations with highest fitness (Zhan and McDonald 2004).

In the present study 84 different bands, which ranged from 8.000 to $200 \mathrm{bp}$, were generated. In contrast, Czembor and Arseniuk (1999) reported bands from 2.176 to $154 \mathrm{bp}$, whereas others reported bands from 2.300 to 200 bp (Boeger et al. 1993; Chen et al. 1994). Our results showed that the ISSR primers (ATC) $)_{7}$ and $(G T G)_{5}$ generated the highest polymorphism between isolates and detected polymorphic bands in 38 isolates among the 83 isolates amplified. Czembor and 
Arseniuk (1999) reported similar results with the ISSR primer $(\text { ATC })_{7}$. The results of this study agree with those of Czembor and Arseniuk (1999) about the utility of ISSR molecular markers for polymorphic detection among $M$. graminicola isolates.

The fact that 43 isolates produced no amplification with this set of primers could have been the result of many factors, such as the absence of repeat sequences, and the mispriming due to sequence differences in priming site, etc. Therefore, these isolates should be tested with another set of primers in order to determine whether they are identical isolates. After repeating these isolates at least four times we assumed that they are identical for the set of primers used in this work. We found that most of the isolates from the wheat subregion IV amplified with at least one primer and were located in cluster I, whereas 24 of the 54 isolates from 9 de Julio and three of the six isolates of Pla did not amplify with any of the primers used in this study, indicating that they most likely belong to different clusters. This seems to indicate that the isolates from 9 de Julio and Pla (wheat subregion II South) probably have molecular patterns different from those from Necochea and Tres Arroyos (wheat subregion IV). However, there is an important gene flow $(\mathrm{Nm}=7.21$ or 11.37$)$ between populations from subregion II South and subregion IV. Schnieder et al. (2001) also assumed constant gene flow over five populations from Germany. Also, working with Argentinean populations, Jürgens et al. (2006) suggested regional gene flow between populations ARG1 (Los Hornos-subregion II South) and ARG2 (Balcarce-subregion IV). The sexual ascospores of $M$. graminicola have the potential to move at least several hundred meters (Shaw and Royle 1989), perhaps over tens of kilometers, indicating their potential as a source of genetic exchange between spatially distant populations.

The work presented here has laid the foundation for future studies by providing valuable information on the genetic diversity of the Argentinean population of $M$. graminicola. The knowledge about the genetic structure of the Argentinean population of M. graminicola was expanded to more isolates in different wheat subregions. Also, differences in the genetic structure of the population in some locations of the subregions II South and IV were noted, reinforcing the findings of previous works. The high degree of genetic diversity among isolates compared in this study characterizes a diverse population of $M$. graminicola in some locations of the two Argentinean wheat subregions. Better knowledge of the pathogen population may help in the development of a successful disease management program, particularly in the production of resistant cultivars, effective fungicides and biological control agents (Moreno et al. 2008). Thus, the findings of this work may help to select a huge set of completely different isolates with different molecular patterns to test a set of Argentinean cultivars and foreign lines with known resistance.

Acknowledgments This work was supported by grants provided by ANPCyT (Agencia Nacional de Promoción Científica y Tecnológica) (PICT 08-14489), Universidad Nacional de La Plata (A189) and Consejo Nacional de Investigaciones Científicas y Técnicas (CONICET).

We thank Fabiana Consolo and Clara Albani (FIBA (Fundación para Investigaciones Biológicas Aplicadas)-Mar del Plata) for their generous cooperation during the molecular tests.

\section{References}

Annone, J., Calzolari, A., Polidoro, O., \& Conta, H. (1991). Efecto de la mancha de la hoja causada por Septoria tritici sobre el rendimiento. Inta EEA Pergamino. Informe $\mathrm{n}^{\circ} 122$.

Annone, J., Conta, H., Polidoro, O., \& Calzolari, A. (1993). Información adicional sobre el efecto de 'mancha de la hoja' causada por Septoria tritici sobre los rendimientos. Inta EEA Pergamino. Informe $\mathrm{n}^{\circ} 146$.

Boeger, J. M., Chen, R. S., \& McDonald, B. A. (1993). Gene flow between geographic populations of Mycosphaerella graminicola (anamorph Septoria tritici) detected with restriction fragment length polymorphism markers. Phytopathology, 83, 1147-1154.

Bornet, B., \& Branchard, M. (2001). Nonanchored inter sequence repeat (ISSR) markers: reproducible and specific tools for genome fingerprinting. Plant Molecular Biology Report, 19, 209-215.

Chen, R. S., Boeger, M., \& McDonald, B. A. (1994). Genetic stability in a population of a pathogen in fungus over time. Molecular Ecology, 3, 209-218.

Chen, R. S., \& McDonald, B. A. (1996). Reproduction plays a major role in the genetic structure of populations of the fungus Mycosphaerella graminicola. Genetics, 142, 1119-1127.

Cordo, C. A., Linde, C. C., Zhan, J., \& McDonald, B. (2006). Genotypic diversity of the wheat leaf blotch pathogen (Septoria tritici) in Buenos Aires province. Sociedad Argentina Botánica, 41, 293-305.

Cordo, C. A., Perelló, A. E., Alippi, H. E., \& Arriaga, H. O. (1990). Presencia de Mycosphaerella graminicola (Fuckel) Schroeter teleomorfo de Septoria tritici Rob. ex Desm. en trigos maduros de la Argentina. Revista Facultad Agronomía, 66(67), 49-55. 
Czembor, P. C., \& Arseniuk, E. (1999). Study of genetic variability among monopycnidial and monopycnidiospore isolates derived from single pycnidia of Stagonospora ssp. and Septoria tritici with the use of RAPD-PCR, MP-PCR and rep-PCR techniques.. Phytopathology, 147, 539-546.

Eyal, Z., Scharen, M. D., Dhuffman, M., \& Prescott, J. M. (1985). Global insights into virulence frequencies of Mycosphaerella graminicola. Phytopathology, 75, 14561462.

Eyal, Z., Scharen, A. L., Prescott, J. M., \& van Ginkel, M. (1987). The Septoria diseases of wheat: Concepts and methods of disease management. México, D.F: International Maize and Wheat Improvement Center (CIMMYT).

Ferreira, M. E., \& Grattapaglia, D. (1998). Introdução ao uso de marcadores moleculares em análise genética (3rd ed.). Brasilia, D.F., Brazil: Embrapa-Cenargen.

Goodwin, S., van der Lee, T., Cavaletto, J., Hekkert, B., Crane, C., \& Kema, G. (2007). Identification and genetic mapping of highly polymorphic microsatellite loci from an EST database of the septoria tritici blotch pathogen Mycosphaerella graminicola. Fungal Genetics and Biology, 44, 398-414.

Jürgens, T., Linde, C., \& McDonald, B. (2006). Genetic structure of Mycosphaerella graminicola populations from Iran, Argentina, and Australia. European Journal of Plant Pathology, 115, 223-233.

Kabbage, M., Leslie, J. F., Zeller, K. A., Hulbert, S. H., \& Bockus, W. W. (2008). Genetic diversity of Mycosphaerella graminicola, the causal agent of septoria tritici blotch, in Kansas winter. Journal of Agricultural, Food and Environmental Sciences, 2(1).

Kema, G. H. J., Goodwin, S. B., Hamza, S., Verstappen, E. C. P., Cavaletto, J. R., van der Lee, T. A. J., et al. (2002). A combined AFLP and RAPD genetic linkage map of Mycosphaerella graminicola, the septoria tritici leaf blotch pathogen of wheat. Genetics, 161, 1497-1505.

Kema, G. H. J., Verstappen, E. C. P., Todorova, M., \& Waalwijk, C. (1996). Successful crosses and molecular tetrad and progeny analysis demonstrate heterothallism in Mycosphaerella graminicola. Current Genetics, 30, 252-258.

Kema, G. H. J., Verstappen, E., van der Lee, T., Mendes, O., Sandbrink, H., Klein-Lankhorst, R., et al. (2003). Gene hunting in Mycosphaerella graminicola. Proceedings of the 22nd Fungal Genetics Conference (Asilomar, CA, USA).

King, J. E., Cook, R. J., \& Melville, S. C. (1983). A review of Septoria diseases of wheat and barley. Annals of Applied Biology, 103, 345-373.

Linde, C. C., Zhan, J., \& McDonald, B. A. (2002). Population structure of Mycosphaerella graminicola: from lesions to continents. Phytopathology, 92, 946-955.

McDonald, B. A., \& Martinez, J. P. (1990). DNA restriction fragment length polymorphism among Mycosphaerella graminicola (anamorph Septoria tritici) isolates collected from a single wheat field. Phytopathology, 80, 1368-1373.

Medini, M., \& Hamza, S. (2008). Pathotype and molecular characterization of Mycosphaerella graminicola isolates collected from Tunisia, Algeria, and Canada. Journal of Plant Pathology, 90, 65-73.
Meng, X., \& Chen, W. (2001). Applications of AFLP and ISSR techniques in detecting genetic diversity in the soybean brown stem rot pathogen Phialophora gragata. Mycology Research, 105, 936-940.

Moreno, M. V., Stenglein, S. A., Balatti, P. A., \& Perelló, A. E. (2008). Pathogenic and molecular variability among isolates of Pyrenophora tritici-repentis, causal agent of tan spot of wheat in Argentina. European Journal of Plant Pathology, 122, 239-252.

Nei, M. (1972). Genetic distance between populations. American Naturalist, 106, 283-292.

Nei, M., \& Li, W. H. (1979). Mathematical model for studying genetic variation in terms of restriction endonucleases. Proceedings of the National Academy of Sciences USA, 76, 5269-5273.

Rajaram, S. (1999). Historical aspects and future challenges of an international wheat program. In M. van Ginkel, A. McNab, \& J. Krupinsky (Eds.), Septoria and Stagonospora diseases of cereals. A compilation of global research (pp. 1-17). Ciudad de Mexico, D.F., México: CIMMYT.

Razavi, M., \& Hughes, G. R. (2004). Molecular variability of Mycosphaerella graminicola as detected by RAPD markers. Journal of Phytopathology, 152, 543-548.

Rohlf, F. J. (1998). NTSYS-pc. Numerical taxonomy and multivariate analysis system. Setauket, NY, USA: Exeter Software.

Sartorato, A. (2004). Pathogenic variability and genetic diversity of Phaeoisariopsis griseola isolates from two counties in the state of Goias, Brazil. Journal of Phytopathology, 152, 385-390.

Schnieder, F., Koch, G., Jung, C., \& Verreet, J. A. (2001). Genotypic diversity of the wheat leaf blotch pathogen Mycosphaerella graminicola (anamorph) Septoria tritici in Germany. European Journal of Plant Pathology, 107, 285-290.

Shaw, M. W., \& Royle, D. J. (1989). Airborne inoculums as major source of Septoria tritici (Mycosphaerella graminicola) infections in winter wheat crops in the UK. Plant Pathology, 38, 35-43.

Simon, M. R., Cordo, C. A., Perello, A. E., \& Struik, P. C. (2003). Influence of nitrogen supply on the susceptibility of wheat to Septoria tritici. Journal of Phytopathology, 151, 283-289.

Simon, M. R., Perello, A. E., \& Cordo, C. A. (1996). Influencia de infección tardía de Septoria tritici Rob. Ex Desm. Sobre el peso de mil granos y algunos parámetros de calidad en Triticum aestivum. Investigación Agraria, Producción y Protección Vegetales, 11, 162-171.

Simon, M. R., Perello, A. E., Cordo, C. A., \& Struik, P. C. (2002). Influence of Septoria tritici on yield, yield components and test weight of wheat under two nitrogen fertilization conditions. Crop Science, 42, 1974-1981.

Stoddart, J. A., \& Taylor, J. F. (1988). Genotypic diversity: estimation and prediction in samples. Genetics, 118, 705-711.

Tautz, D., \& Renz, M. (1984). Simple sequences are ubiquitous repetitive components of eukariotic genomes. Nucleic Acids Research, 23, 249-255.

Wagara, I. N., Mwang'ombe, A. W., Kimenju, J. W., Buruchara, R. A., Jamnadass, R., \& Majiwa, P. A. O. 
(2004). Genetic diversity of Phaeoisariopsis griseola in Kenya as revealed by AFLP and group-specific primers. Journal of Phytopathology, 152, 235-242.

Wolfe, A. D., \& Liston, A. (1998). Contributions of PCR-based methods to plant systematics and evolutionary biology. In D. E. Soltis, P. S. Soltis, \& J. J. Doyle (Eds.), Plant molecular systematics II (pp. 43-86). Dordrecht, the Netherlands: Kluwer.

Wolfe, A. D., Xiang, Q.-Y., \& Kephart, S. R. (1998). Assessing hybridization in natural populations of Penstemon (Scrophulariaceae) using hypervariable inter simple sequence repeat markers. Molecular Ecology, 7, 1107-1125.
Zhan, J., \& McDonald, B. A. (2004). The interaction among evolutionary forces in the pathogenic fungus $M$. graminicola. Fungal Genetics and Biology, 41, 590-599.

Zhan, J., Pettway, R. E., \& McDonald, B. A. (2003). The global genetic structure of the wheat pathogen Mycosphaerella graminicola is characterized by high nuclear diversity, low mitochondrial diversity, regular recombination, and gene flow. Fungal Genetics and Biology, 38, 286-297.

Zietkiewicz, E., Rafalski, A., \& Labuda, D. (1994). Genome fingerprinting by simple sequence repeat (SSR)-anchored polymerase chain reaction amplification. Genome, 20, 176-183. 